\title{
The trouble with sanctions: Organizational responses to deviant anger displays at work
}

\author{
Deanna Geddes \\ Temple University, USA

\section{Lisa T Stickney} \\ University of Baltimore, USA
}

\begin{abstract}
This article examines management and coworker reactions to employee anger expressions that violate salient emotion display norms, for example, deviant anger, and explores whether these reactions can promote subsequent positive change at work. Full-time US employees volunteered information about workplace anger expressions they personally witnessed and felt 'went too far'. Using open-ended survey questions, we identified three categories of deviant anger (physical acts, intense verbal displays, and inappropriate communication), as well as various formal and informal sanctioning and supportive responses initiated by organizational observers. Additional data collection and generalized linear modeling analysis revealed that when coworkers and management responded supportively to the angry employee (rather than with sanctions or doing nothing), favorable change occurred, improving the problematic situation. Implications for future research, management practices, and employee socialization are discussed.
\end{abstract}

\section{Keywords}

aggression, compassionate cultures, emotion in organizations, organizational deviance, sanctions, workplace anger

No longer are workplaces viewed simply as rational social environments that produce only reasoned discourse and interactions that consistently project emotional neutrality and politeness. Organizations are emotional arenas, such that daily 'hassles and uplifts'

\footnotetext{
Corresponding author:

Deanna Geddes, Department of Human Resource Management, Temple University, I80 I Liacouras Walk A353 Alter Hall (006-13), Philadelphia, Pennsylvania 19122-6083, USA.

Email: geddes@temple.edu
} 
can generate numerous emotions and exchanges among employees (Ashforth and Humphrey, 1995; Fineman, 1993; Rafaeli and Sutton, 1989; Weiss and Cropanzano, 1996). Related research suggests that as organizations require more frequent interactions among their members, this increases the likelihood of felt as well as expressed anger at work (Sloan, 2004; see also Averill, 1993). Thus, it is important that scholars and practitioners seek to better understand anger in the workplace - especially its most challenging forms - organizational member reactions to these expressions, and how such factors impact effective situational change in the workplace.

Employee anger is a 'hot' and discrete negative emotion often aroused by inferences of responsibility in others for some form of mistreatment or impropriety at work (Aquino et al., 2004; Gibson and Callister, 2010). The likelihood that an employee's felt anger is expressed reflects not only individual traits and tendencies, but also salient social and/or organizational limitations and allowances regarding emotion expression. While some employees suppress felt anger at work (Gross and John, 2003), those who express their anger subject these emotional displays to evaluation by 'organizational observers' (Geddes and Callister, 2007). These consist of anger targets, witnesses, and various others - including management - made aware of the emotional episode.

Some anger expressions at work will be evaluated by observers as appropriate, given relevant circumstances such as sufficient provocation, or when an emotional display incorporates limited markers of intensity. Not surprisingly, instances of acceptable anger displays are not likely to provoke punitive responses by organizational members. However, anger expression also may be judged as unacceptable or 'deviant', meaning it deviates from organizational norms of tolerable emotion displays (Geddes and Callister, 2007). While some organizations allow a wide range of workplace anger displays, others will consider even token displays of employee anger entirely unacceptable (Ashkanasy et al., 2002; Gibson et al., 2009; Kramer and Hess, 2002). Consequently, examples of 'deviant anger' can vary from simply unexpected (e.g. shouting an expletive or sending an inflammatory email) to frightening (e.g. punching a wall or threatening bodily harm). What is consistent across all forms of deviant anger at work, however, is the possibility of subsequent formal as well as informal sanctioning.

Employees expressing deviant anger may be terminated by management or receive various other formal responses such as a written warning, probation, or suspension; for example, when deviant anger manifests as a seriously aggressive act, (e.g. physical violence), organizational sanctioning is not only probable, it is undoubtedly appropriate. Various deviant anger displays also may promote informal sanctioning as coworkers distance themselves or retaliate. However, supportive responses, in contrast to sanctions, also are possible following deviant anger displays. Instead of retaliating or initiating formal sanctions following an inappropriate display of anger, coworkers and management might attempt to calm and comfort the individual, express concerned interest, and initiate discussions to better understand and address the initial, problematic situation prompting the emotional outburst.

Currently we know little about the effect of organizational observers who reinforce formal or informal emotion display norms and rules through sanctioning (Rafaeli and Sutton, 1989) or, alternatively, who expand their company's 'zone of expressive tolerance' (Fineman, 2000), establishing more supportive environments and responses to deviant anger displays. Consequently, to better understand the emotional arena of work, it is important to consider 
the unique influence of these 'spectators and referees'. Studies reported here examine the key role organizational observers play following deviant anger displays and explore: 1) how deviant anger displays and supportive work environments affect manager and coworker sanctioning and supportive behavior, and 2) how these responses by organizational observers impact effective change in the workplace following an anger episode.

\section{The dual threshold model and emergent views of workplace anger}

For this research, we adopt a framework and conceptualizations put forth by the Dual Threshold Model (DTM) of workplace anger (Geddes and Callister, 2007; see Figure 1). The DTM posits that involved organizational observers, perhaps more than the angry actor, determine whether expressed workplace anger helps or hurts organizations and its members. Our studies are preliminary efforts to test empirically relationships among DTM constructs of deviant anger, organizational observers, supportive work environments, and supportive versus sanctioning responses to workplace anger.

Geddes and Callister (2007) propose that negative individual and organizational consequences from workplace anger, in general, increase in one of two situations. The first is when organizational members suppress their felt anger either by silencing it (i.e. 'silent anger') or expressing it only to those unrelated to or unable to address the infuriating

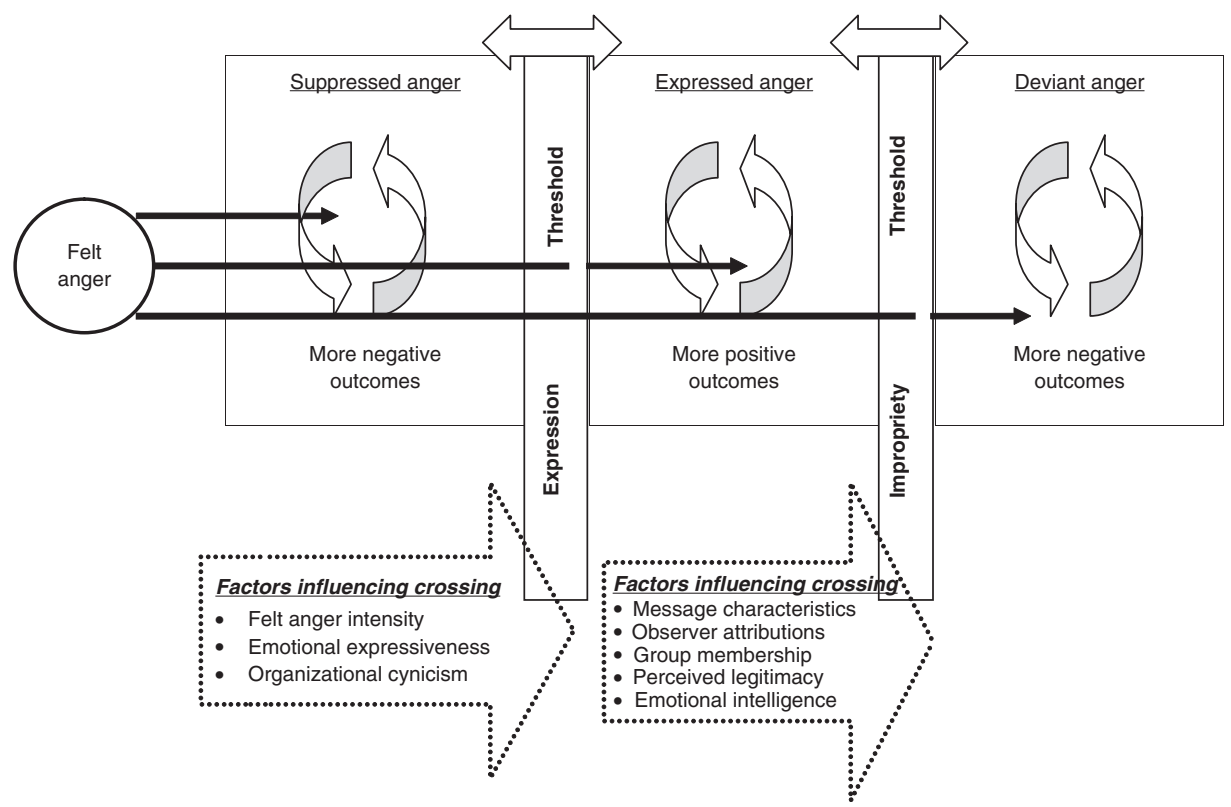

Figure I The dual threshold model of workplace anger. Used with permission of Academy of Management Review 
event (i.e. 'muted anger'). In both cases, the individual fails to cross an 'expression threshold' at work. In the first example, the employee is personally silent and in the second, she or he is 'organizationally silent' meaning that the anger is intentionally hidden from those who triggered, or could do something to remedy, the problematic situation (Milliken et al., 2003; Perlow and Williams, 2003; Pinder and Harlos, 2001).

Relevant to our research is the second workplace anger situation promoting negative consequences - what the DTM labels deviant anger. This is represented visually in the model by organizational member anger crossing not only the expression threshold, but also an 'impropriety threshold', meaning their anger is expressed in a manner deemed socially unacceptable by organizational observers. Geddes and Callister (2007) argue that negative individual consequences, in particular, result from deviant anger displays since these often prompt sanctioning. Negative organizational consequences also may result if the deviant anger itself is damaging, leads to escalation, and/or if angry, but valuable organizational members are offended or removed by subsequent sanctioning. Positive individual and organizations outcomes, according to the DTM, are most likely when workplace anger stays between the expression and impropriety thresholds. In other words, benefits from workplace anger increase when employees express anger to relevant others in a manner fellow organizational members find acceptable and when organizations allow sufficient space between thresholds for anger expression.

The DTM's two thresholds in relation to each other define the range of acceptable versus unacceptable workplace anger expressions. Thus, organization emotion display norms are represented visually in the DTM with the relative placement of the two thresholds. Space between thresholds can be limited so as to suppress and/or restrict anger displays, or expanded to reflect more tolerant, supportive policies and practices. Expression and impropriety thresholds close together suggest a more sanctioning environment, while thresholds spaced further apart indicate a more supportive environment for anger expression. Threshold placement reflects the individual and/or collective perceptions of organizational members who observe, interpret, and respond to displays of anger at work. As such, our focus on understanding the perceptions of organizational observers provides an empirical examination of the DTM.

This unique model reflects an emergent view of workplace anger, in contrast to traditional views. Traditionally, workplace anger displays are considered at best, unprofessional, and at worst, hostile acts. In particular, intense displays of anger - a common characteristic of what is identified here as deviant anger - are portrayed as intentionally harmful, aggressive behaviors, and thus, fundamentally antisocial and destructive. Scholars perpetuate this view when workplace anger is used synonymously with 'workplace aggression' (Neuman and Baron, 1998), 'organizational violence', (Giacalone and Greenberg, 1997; O’Leary-Kelly et al., 1996), and 'revengeful acts' (Bies et al., 1997; Skarlicki and Folger, 1997). Established models of anger expression (Fox and Spector, 1999; Spielberger et al., 1985) also regularly link anger with aggression and hostility. Even if anger expression is judged as not intentionally harmful, but instead more insensitive as with instances of workplace incivility (Andersson and Pearson, 1999; Ellis, 2001), or inappropriate as with deviant work behavior (Lee and Allen, 2002; Robinson and Bennett, 1995), anger expression that violates emotion display norms is typically seen as a threat to the wellbeing of an organization, its members, or both. Consequently, sanctioning anger expression is forwarded as an appropriate, desirable, and even necessary response. 
In contrast to traditional views, the DTM and other emergent views of workplace anger argue that anger expression is often not intentionally harmful or aggressive (see Clore and Ortony, 1991) and that anger and aggression often operate independently (Torestad, 1990). Averill (1982) comments: 'Anger no more causes aggression than a blueprint causes the construction of a building' (p. 189). Rather than inherently aggressive or abnormal, felt and expressed anger are framed as a natural response to intolerable situations such as workplace inefficiency, injustice, and/or impropriety (Averill, 1993; Canary et al., 1998). Employees become angry when their expectations are violated, such as when they experience unethical or unfair practices by supervisors or coworkers, or when colleagues' obstruction, inaction, and/or disrespect inhibits employee goal attainment (Fox and Spector, 1999; Tepper, 2000; Torestad, 1990).

The emergent perspective also argues expressed anger can provide valuable information and may serve a pro-social function for the organization (Clore et al., 2001; Côté, 2005; Mikulincer, 1998). Anger expression can signal problems at work (e.g. injustices, inefficiencies, improprieties) that negatively impact fellow employees and the organization as a whole, not just the angry employee (Geddes and Callister, 2007; Kramer and Hess, 2002; Robinson and Bennett, 1995). Thus, the individual expressing anger over work may potentially function as a useful 'change agent', helping management identify and address existing problems, and facilitating improved organizational functioning and learning (Huy, 1999).

Further, some argue increased interpersonal informality in the workplace increases our tolerance for more impulsive and expressive behavior among organizational members (Mastenbroek, 2000). In such environments, displayed anger might be perceived not only as acceptable, but appreciated or even honored (Meyerson, 2000), especially when considering the alternative difficulties associated with silent rage and hidden frustration (Morrison and Milliken, 2000; Perlow and Williams, 2003). In this instance, visibility allows for, minimally, a distinct response by the organization, and, potentially, a favorable consequence.

Traditional and emergent views of workplace anger offer alternative possibilities regarding the nature and potential impact of anger. With either approach, however, whether expressed anger proves ultimately beneficial or harmful to the organization depends on how its members respond to these displays. Traditionally, expressed anger responded to with sanctioning is seen as most helpful for the organization, while the emergent view offers the possibility that supportive responses may often prove more beneficial. For either perspective, 'no-response' following expressed anger appears the more problematic option. Given that deviant anger is the most likely form of expressed anger to provoke an organizational response, we review this construct in the following section and offer relevant hypotheses.

\section{Deviant anger and sanctions}

Interest in organizational observers, in particular, guided our focus on anger expression that managers and coworkers consider deviant. These anger displays are not only visible and challenging to address, they prompt a full spectrum of potential observer responses including sanctions. The DTM incorporates a combined reactive and normative approach in defining deviant anger (Spreitzer and Sonenshein, 2004). Deviance, as it relates to 
expressions of anger, reflects idiosyncratic as well as more universal norms of socially unacceptable behavior (Warren, 2003) and manifests in a wide range of expressive forms.

Geddes and Callister (2007) acknowledge organizational observers may see anger expressions as deviant because a person raised his or her voice, slammed a door, sent an all-caps email, or uttered an expletive (see also Lord et al., 2002). Nevertheless, deviant anger displays also may include intentionally harmful, aggressive acts such as physical violence, verbal abuse, or hateful emails to a fellow employee - characterized by Robinson and Bennett (1995) as 'serious deviance'. Research on workplace aggression consistently reports that physical violence at work is extremely rare; verbal aggression is more common, though usually indirect and passive to avoid detection, rather than easily observable, direct, and active displays (Baron and Neuman, 1998; Baron et al., 1999; Geddes and Baron, 1997). This suggests that many physical or verbal anger displays at work, rather than being aggressive acts revealing malicious intent, may instead indicate outrage at a perceived injustice as well as reduced effort (or ability) to regulate felt emotion (Gross and John, 2003), sometimes referred to as 'emotional hijacking' (Goleman, 1995).

Deviant anger may or may not spring from more honorable intentions, such as challenging an organizational injustice (see Spreitzer and Sonenshein, 2003, 2004). Nevertheless, the classic actor versus observer attribution bias indicates that while actors often justify and attribute their own bad behavior to external factors, they tend not to adopt this explanation as observers. More commonly ascribed are internal traits (Jones and Nisbett, 1972; Ross, 1977) or harmful, conscious intentions (Malle et al., 2007) to account for deviant anger, rather than situational circumstances (e.g. organizational injustices). Given traditional tendencies to equate intense anger expression with hostility or aggression, the DTM asserts that negative individual consequences, such as formal and informal sanctions, increase with deviant anger displays (Geddes and Callister, 2007). We anticipate that more extreme, visible expressions of anger, including physical actions and verbally intense anger expressions, rather than other forms of inappropriate expressions of anger, will likely prompt sanctioning by management and coworkers (see Morrill, 1989; Neuman and Baron, 1998). Therefore, we offer the following hypotheses:

Hypothesis 1a: Deviant anger in the form of physical acts or intense verbal displays, in contrast to other forms of inappropriate communication, increases formal sanctioning by management.

Hypothesis 1b: Deviant anger in the form of physical acts or intense verbal displays, in contrast to other forms of inappropriate communication, increases informal sanctioning by coworkers.

\section{Sanctions and outcomes}

Sanctioning deviant anger is an effort by organizations to maintain order and reassert codes of conduct. Management may impose formal sanctions via write-ups, suspensions, probation or even dismissal, while coworkers may informally sanction by distancing themselves or responding in a more direct, retaliatory manner. Geddes and Callister (2007) propose that formal sanctions by management are most likely when observers, particularly those with higher status, characterize the anger display as deviant and when the action is interpreted as aggressive. 
Ironically, when companies choose to sanction organizational members expressing deviant anger, these actions may divert attention and resources from correcting the initial, anger-provoking event that triggered the employee's emotional outburst. Concentrating attention to reprimand and punish the angry individual may thwart potentially valuable, timely conversations regarding organizational policies and/or practices that may require significant review and modification (Canary et al., 1998; Milliken et al., 2003; Tavris, 1984). The focus shifts to eliminate the problematic, angry individual - not the problematic workplace situation (Geddes and Callister, 2007). Unrelated others - frequently part of the employees' support system - also may become involved in the emotional episode. For instance, punishing organizational members for deviant anger reactions to conditions or circumstances they find intolerable may have a chilling and demoralizing effect on fellow employees who sympathize with their frustration; it also may incite aggressive acts if employee supporters become incensed and retaliate against management (Hatfield et al., 1994).

Given perceptions of 'just cause' that often accompany anger displays (Lucero and Allen, 2006), angered employees who already feel wronged may perceive further mistreatment by disciplinary action - especially if perceived as disproportionately harsh. This can damage employee-management relationships (Lucero and Allen, 1998) and perhaps contribute to reduced organizational commitment, motivation, and productivity. If employees are dismissed, their potentially valuable contributions are lost, along with organizational knowledge and learning opportunities (Kiefer, 2002; Nonaka et al., 2001). Informal, retaliatory responses between the angry employee and fellow organizational members (Bies et al., 1997; Friedman et al., 2004; Tavris, 1982) may prove particularly destructive as these may be seen as less legitimate and more personally offensive. Cycles of incivility (Andersson and Pearson, 1999) or aggression (Robinson and O'Leary-Kelly, 1998) may develop; further damaging morale and positive feelings toward fellow coworkers, management, and the organization itself. Therefore, we offer the following hypotheses:

Hypothesis 2a: Formal sanctions imposed by management in response to deviant anger decrease effective situational change at work.

Hypothesis 2b: Informal sanctions imposed by coworkers in response to deviant anger decrease effective situational change at work.

\section{Support and outcomes}

Only anger displays considered deviant are likely to produce sanctioning responses by organizational observers. Nevertheless, the DTM suggests strong emotion expressed in more tolerant and/or compassionate cultures will promote more supportive responses by organizational members. Further, Geddes and Callister (2007) argue that more supportive responses toward angry employees can prove beneficial not only for the angry individual, but the organization itself. Thus, it is important to consider the association between supportive work environments and supportive responses to deviant anger by organizational observers, and to examine whether supportive responses to deviant anger can promote favorable situational change at work. 
Providing emotional support typically involves individual expressions of care, affection, and/or interest, especially during times of obvious emotional distress (Burleson, 2003). Supportive responses typically include expressions of encouragement, appreciation, and even advice meant to help individuals work through their upset and concerns (Burleson, 1994). Related research on compassion argues that noticing, feeling, and responding to another's pain — even emotional hurt manifested as anger — help alleviate that pain and increase organization survival and effectiveness (Kanov et al., 2004; Reich, 1989). Specific to management, models of leadership 'forbearance' suggest that workplaces can benefit from managers who reasonably forbear, that is, show a degree of leniency such as levying sanctions somewhat less than proportional to the offense in the event of 'overwhelming personal difficulties' (Nelson and Dyck, 2005).

Research on social support, in general, shows that coworkers and management are key sources of nontangible support to emotional employees (Viswesvaran et al., 1999). Studies indicate that social support can buffer or psychologically protect upset individuals as well as promote a beneficial effect on all employees, irrespective of their emotional state (Cohen and Wills, 1985; Van Emmerik et al., 2007). Scholars studying compassion also argue that emotional support is a dynamic process that can be found both in individuals and collectivities (Dutton et al., 2006). Thus, support for angry employees should be considered as both an individual response by management and/or coworkers as well as a condition of the work environment.

In the DTM, more tolerant emotion display norms are represented by greater space between the expression and impropriety thresholds and indicate more supportive work environments. Here people are given more opportunity to express strong emotion, including anger, without the likelihood of formal or informal sanctions. Geddes and Callister (2007) argue that when anger is responded to more frequently with support and compassion by organizational members, norms develop that expand the space of acceptable anger expression. Further, when confronted with anger that crosses the impropriety threshold (i.e. deviant anger), organizational observers from more supportive work environments are motivated to respond in a more supportive manner and 'bring the discussion back into the space between thresholds' (p. 736). These supportive responses by organizational members to anger displays in turn can help promote positive outcomes for organizations (Dutton et al., 2006). Therefore, we offer the following hypotheses:

Hypothesis 3a: Supportive work environments increase less punitive, more supportive responses to deviant anger from management.

Hypothesis 3b: Supportive work environments increase less punitive, more supportive responses to deviant anger from coworkers.

Hypothesis 4a: Supportive responses by management to employees who express deviant anger increase effective situational change at work.

Hypothesis 4b: Supportive responses by coworkers to employees who express deviant anger increase effective situational change at work. 


\section{Method}

\section{Pilot study}

To better understand the relationships among deviant anger displays, organizational observer responses, and situational change, we assembled and pilot tested a preliminary survey. The survey went to 32 full-time, office workers of a large public utility subsidiary. Thirteen employees completed and returned usable surveys. Participants provided both specific and general attitudes toward anger and its expression in the organization. Two open-ended questions helped to identify forms of deviant anger expression and formal and informal organizational responses, respectively. The questions asked were:

- If you have personally witnessed someone who you felt went 'too far' when expressing their work-related anger, what did they do that you felt was 'over the top' regarding appropriateness?

- What happened to this individual after he or she went 'too far': formally by the company/management and informally by coworkers?

The two authors transcribed and examined participant responses to each open-ended question. The unit of analysis was defined as a distinguishable action. Once the qualitative data were unitized with 100 percent agreement (see Guetzkow, 1950), both researchers operating separately sorted each response to the respective questions into categories based on their content similarity. After comparing and labeling our respective categories of deviant anger displays, formal responses, and informal responses, the few differences were discussed until there was 100 percent agreement. ${ }^{1}$

Three categories of deviant anger displays emerged from coding responses from the pilot study. 'Inappropriate communication' included demeaning comments, offensive notes or emails, and was typified by comments such as: 'This person publically demeaned another coworker'. By contrast, 'intense verbal displays' included yelling, screaming, swearing, and so on, and was exemplified by a respondent who reported observing 'a screaming match'. 'Physical actions' involved striking, pushing, throwing objects, and so on, and reflected comments such as: 'the guy places mechanical parts against the wall and pushes his tool box into objects'. These categorizations are generally consistent with those found in research on expressed anger and aggression (Averill, 1979; Canary et al., 1998; Geddes and Baron, 1997; Neuman and Baron, 1998) and parallel findings that individuals can distinguish among anger expressions (Sereno et al., 1987).

Examples of witnessed formal responses by management following deviant anger displays helped generate three categories, including; 'Warning' (e.g. 'He got a slight warning'); 'Probation' (e.g. 'The person was given another chance, but was watched closely'); and 'Dismissed' (e.g. 'Someone called the cops and he was removed permanently'). Examples of informal coworker actions helped generate three responses; 'Physical aggression' (e.g. 'She was physically threatened by a coworker'); 'Someone talked to the offender' (e.g. 'We talked about what other options that could have [sic] used and looked 
at training opportunities'); and 'Distancing from offender' (e.g. 'Coworkers seemed to fear this person'). For both formal and informal responses, participants also indicated that at times 'nothing happened'; thus, we identified this as an option for both management and coworker response.

\section{Preliminary study}

Given the small sample size of our pilot study, a second data collection was warranted to assess the adequacy of our categories of anger-related behaviors, expand them if possible, and generate some preliminary results. We revised our survey to include the categories identified from the pilot study regarding deviant anger, formal responses, and informal responses. These were used as response options for type of witnessed deviant anger and organizational response. Further, we included a write-in 'Other' option for these questions as well as an 'I don't know' option for the question asking about subsequent formal and informal reactions to the angry employee. We also included an openended question and asked survey participants to explain about the situation or circumstances that made the employee they observed so angry. Finally, we added a simple outcome measure that asked the observer's perception of: 'What eventually happened regarding the situation that made that person so angry?'. There were three possible responses to this question: $1=$ got worse, $2=$ stayed the same, and $3=$ improved.

When indicating the type of deviant anger display and subsequent organizational response they witnessed, participants were instructed to check all items that applied. This instruction was necessary because some participants in the pilot study described more than one type of witnessed deviant anger display (e.g. 'he kicked a chair and yelled at the boss before slamming the door on the way out'), as well as multiple formal and informal responses by organizational members (e.g. 'I talked to them about what happened, but other employees stopped hanging around the person after that'). ${ }^{2}$

We distributed this survey to 196 participants from a small aerospace and a mechanical services company, advanced (junior or senior) undergraduate business majors, and employed MBA students. All participants worked at least part-time, and 56 percent worked full-time. Fifty-nine percent were female and most (73\%) were Caucasian and under the age of 30 (70\%). Thirty-one percent had held their current job for less than a year, 36 percent for more than one year but less than three years, 16 percent between three and five years, and 17 percent were employed over five years at their current position. They completed the surveys at work or in class, returned them promptly to the researchers, and were assured anonymity and confidentiality.

We reviewed survey respondent descriptions regarding what prompted the employee's anger. Although these responses were not used in our subsequent analyses, they were helpful in providing a richer understanding of the variety of reasons people display anger at work. For instance, respondents reported that people got angry because: 'They think they are given too much work to do' (perceived injustice); 'Shotty [sic] workmanship on parts prior to his operation' (inadequate performance of others); 'She was mad that I turned her in' (perceived improprieties of colleagues); 'Everything was making them upset, person was having a difficult day' (stress); 'She's just jealous', 'a loudmouth personality' (personal traits); 'Copy machine jams' (organizational inefficiencies); and 'Not knowing the organizational hierarchy' (lack of understanding). 
Analysis of the data on deviant anger displays and organizational responses provided useful information on frequency and perceived effects. Participants reported observing various forms of deviant anger displays, including intense verbal displays (75\%), inappropriate, demeaning communication (42\%), and physical actions (23\%). Forty-one percent of respondents knew of some formal response by management following the deviant anger display, 31 percent believed no formal response occurred, and 12 percent indicated the deviant anger incident went unreported. Informal responses by coworkers were reported in 55 percent of the anger incidents, while 26 percent believed there was no specific informal response and 18 percent were unsure.

We also examined the written responses provided in the 'Other' category of the anger questions. Using the same procedure as in the initial survey, we transcribed, unitized, then categorized each response and discussed differences until we reached complete agreement. Based on the results of this data set, we significantly expanded response options for formal and informal responses to deviant anger, including supportive as well as sanctioning actions. We also clarified some existing response items to help interpretation of results. These modified response sets were included in the finalized 'Emotions in the Workplace' questionnaire used for our primary study and are discussed in the following section.

\section{Primary study}

Participants in this study included 194 individuals who acknowledged witnessing an incident of deviant anger at work. All were volunteers and full-time US employees recruited from an eastern healthcare center (26\%), graduate business classes in a large eastern US university (52\%), and working associates of students attending two eastern US business schools (22\%). Fifty-nine percent were female and 87 percent were Caucasian. Table 1 contains the demographic characteristics of study participants.

Table I Demographic characteristics of study participants

\begin{tabular}{|c|c|c|c|}
\hline & Percent & & Percent \\
\hline Sex: & & Number of employees supervised: & \\
\hline Male & 41 & None, not in management & 52 \\
\hline Female & 59 & $\begin{array}{l}\mathrm{I}-10 \\
\mathrm{II}-25\end{array}$ & $\begin{array}{r}36 \\
7\end{array}$ \\
\hline Race: & & More than 25 & 5 \\
\hline White/Caucasian & 87 & & \\
\hline Asian/Pacific Islander & 7 & Annual income: & \\
\hline Black/African-American & 4 & Below $\$ 30,000$ & 26 \\
\hline Hispanic/Latino & I & $\$ 30,000-\$ 74,999$ & 49 \\
\hline Other & 1 & $\begin{array}{l}\$ 75,000-\$ 99,999 \\
\$ 100,000 \text { and over }\end{array}$ & $\begin{array}{l}14 \\
11\end{array}$ \\
\hline \multicolumn{4}{|l|}{ Age: } \\
\hline 30 and under & 44 & Job tenure: & \\
\hline $31-40$ & 23 & Less than one year & 25 \\
\hline $4 I-50$ & 22 & Between one and five years & 53 \\
\hline $5 I-60$ & 9 & Between five and ten years & 14 \\
\hline Over 60 & 2 & More than 10 years & 8 \\
\hline
\end{tabular}




\section{Procedures}

Responses to the 'Emotions in the Workplace' questionnaire provided study data. Respondents reflected and commented on a specific, memorable event at work they personally witnessed in which "someone at work went "too far" when expressing their work-related anger'. We framed questions involving this socially-unacceptable display of anger from an observer's perspective to minimize potential social desirability bias. With the deviant anger incident in mind, respondents replied to relevant questions and provided demographic information. Respondents placed completed surveys in an envelope, sealed it, and returned the filled envelope to either their contact person or to collection boxes at work. All were ensured confidentiality and anonymity.

\section{Measures}

Deviant anger The three categories of observable, socially-unacceptable anger expressions identified in our pilot study served as separate independent variables: 'Inappropriate communication', 'Intense verbal displays', and 'Physical actions'. Survey instructions directed respondents to choose anger displays that described what they witnessed. Selected response options were coded as one and those not selected were coded as zero. Category frequencies for these and all multiple response option variables are used in the correlation table (see Table 2).

Formal responses Consistent with Geddes and Callister's (2007) DTM's conceptualization of supportive and sanctioning anger responses, we created two variables - management support and management sanctions - to assess how management responded to the angry employee. Survey respondents selected all known management actions toward the employee following the deviant anger display. Any formal action taken by management subsequent to a deviant anger display could be construed as a sanction. However, based on our preliminary study, one option emerged - 'Management talked to the offender' and was determined to be the least punitive, most supportive formal response by management. This served as our formal support variable, management support. More punitive management sanctioning behavior responses identified in the pilot and preliminary studies included a clarified 'Written warning', in addition to 'Probation', 'Suspended', 'Dismissed', and 'Other (please specify)'. Additional response options included: 'No formal sanctioning occurred', 'Incident not reported', and 'I don't know'. Each of these response options received a value of one if selected and zero if not. Cases in which the respondent was not aware of a formal response or when the anger incident was not reported to management were removed from subsequent analysis.

From the multiple, dummy coded formal sanction response options, we created management sanctions, a single formal sanction variable for each case. This made its use as an independent and dependent variable more manageable and logical for statistical analysis. If a survey respondent selected non-dismissal sanction options (i.e. Written warning, Probation, Suspension), the formal sanction variable was assigned a value of one. If participants selected 'Dismissal' as the formal response, this was assigned a value of two. Thus, management sanctions received zero if no formal sanctioning responses were 
selected, one for any selected non-dismissal sanctions, and two for selected sanctions that included dismissal. Given that dismissal is clearly the most severe sanction possible by management, this categorical coding also reflects an intuitive, lesser-greater sanctioning response from management. The formal sanction variable served as the dependent variable in Hypothesis 1a and as an independent, predictor variable in Hypothesis 2a. Management support served as the dependent variable in Hypothesis $3 \mathrm{a}$ and as an independent, predictor variable in Hypothesis 4a.

Informal responses Also consistent with the DTM (Geddes and Callister, 2007), we created two variables, coworker support and coworker sanctions to assess informal responses to the angry employee by coworkers. Based on the results of the preliminary study, it was difficult to interpret the coworker talking with the employee as either sanctioning or supportive. Thus, we expanded the response options to include what could more clearly be identified as supportive acts by colleagues: 'Someone talked to the offender about his/her behavior in a supportive, non-assertive manner' and 'Someone talked to the offender about his/her behavior in a supportive, assertive manner', with the later suggesting a more forceful and challenging, but non-aggressive, approach. Such differentiations in conversational tone and demeanor would be more observable among fellow coworkers than management talking with the employee, given management's inclination to discipline in private.

Informal sanction response options included the previously identified 'People distanced themselves from the offender', as well as two new options obtained from the preliminary study write-in 'Other' option: 'Someone responded with verbal aggression', and 'Someone responded with physical aggression'. We used the term aggression to distinguish sanctioning responses that appeared intentionally hurtful from those that were clearly assertive, but still perceived as supportive toward the employee. Other relevant response options for participants included: 'No informal sanctioning occurred' and 'I don't know'. Each response option was coded as one if selected and zero if not. We eliminated cases from subsequent analysis in which the respondent did not know about informal responses.

Similar to our management sanction variable, for each case we created single coworker sanction and coworker support variables from our multiple, dummy coded informal response options. Here, however, we summed response options for coworker sanctions and did the same for coworker support, making each a frequency-based or 'count' variable. For example, if the respondent selected 'coworker distanced self from the angry individual' and 'coworker responded in a verbally aggressive manner', the value of coworker sanctions was two. Coworker sanctions had an initial response range of zero (no informal sanctions selected) to three (three informal sanction options selected). However, no one selected the physical aggression option, reducing the response range from zero to two. Coworker support had a response range varying from zero (no informal support items selected) to two (two informal support items selected). Using a frequencybased variable also reflected a lesser-greater sanctioning or supportive response from coworkers. In other words, multiple sanctioning or supportive responses from a single person or several individuals might have an aggregated or synergistic positive or negative effect on the individual or situation (see Youndt et al., 1996). Coworker sanctions 
was the dependent variable in Hypothesis $1 \mathrm{~b}$ and an independent variable in Hypothesis 2b. Coworker support was the dependent variable in Hypothesis $3 \mathrm{~b}$ and an independent variable in Hypothesis $4 b$.

Perceptions of work environment We developed a measure consistent with the DTM's (Geddes and Callister, 2007) conceptualization of supportiveness in the work environment. Respondents assessed their work environment using a forced-choice adjective pair format. We used five sets of opposing adjectives anchored on a 7-point scale. The adjectives were unpleasant-pleasant, hostile-friendly, rude-polite, destructive-nurturing, and obstructive-supportive. A factor analysis (principle axis factoring) of the five items produced a one-factor solution with the factor explaining 73.7 percent of the variance in the underlying items. The alpha coefficient for these items was .93. Higher scores of the averaged items reflected perceptions of a more positive, supportive work environment. This measure served as a predictor variable for Hypothesis $3 \mathrm{a}$ and $3 \mathrm{~b}$ and as a control in models testing the other hypotheses.

Situational change Situational change was the organizational outcome and dependent variable for Hypotheses 2a, 2b, 4a, and 4b. This measured a Gestalt perception of whether or not witnesses observed effective change within the work environment following the anger incident and subsequent response. Survey respondents indicated their overall perceptions of the anger-provoking situation by answering the same question as in the preliminary study: 'What eventually happened regarding the situation that made that person so angry?'. Response options were that the situation: $1=$ got a lot worse, 2 $=$ got a little worse, $3=$ stayed the same, $4=$ got a little better, and $5=$ got a lot better $($ mean $=3.59, \mathrm{SD}=.93)$.

Controls Control variables included witness gender $(1=$ male, $0=$ female $)$, age, race ( 1 = white, 0 = non-white), supervisory status, and recency of the anger incident. Age was assessed with a categorical variable bearing a value between one and five: $1=$ age 30 and under, $2=$ age 31 to $40,3=$ age 41 to $50,4=$ age $51-60$, and $5=$ over 60 years old. Witness supervisory status was based on the number of employees the witness/ survey respondent supervised $(1=$ none, I'm not in management, 2 = between one and 10 employees, 3 = between 11 and 25 employees, and $4=$ more than 25 employees supervised). Recency of anger incident was assessed using a single item, interval variable with five possible response options: $1=$ within the last day or two, $2=$ some other time during the past week, $3=$ more than a week but less than a month ago, $4=$ more than a month, but less than six months ago, and $5=$ more than 6 months ago.

Given that hierarchical status of not only the witness, but also the individual displaying deviant anger could affect the likelihood and nature of sanctions (Geddes and Callister, 2007; Lovaglia and Houser, 1996; Tiedens, 2000), we included a second status control variable that indicated the relative status of the angry individual. That is, if the situation was provoked by someone within the organization, survey respondents indicated if the excessively angry individual was a subordinate (1), peer (2), or supervisor (3) of the individual who made him or her angry. 


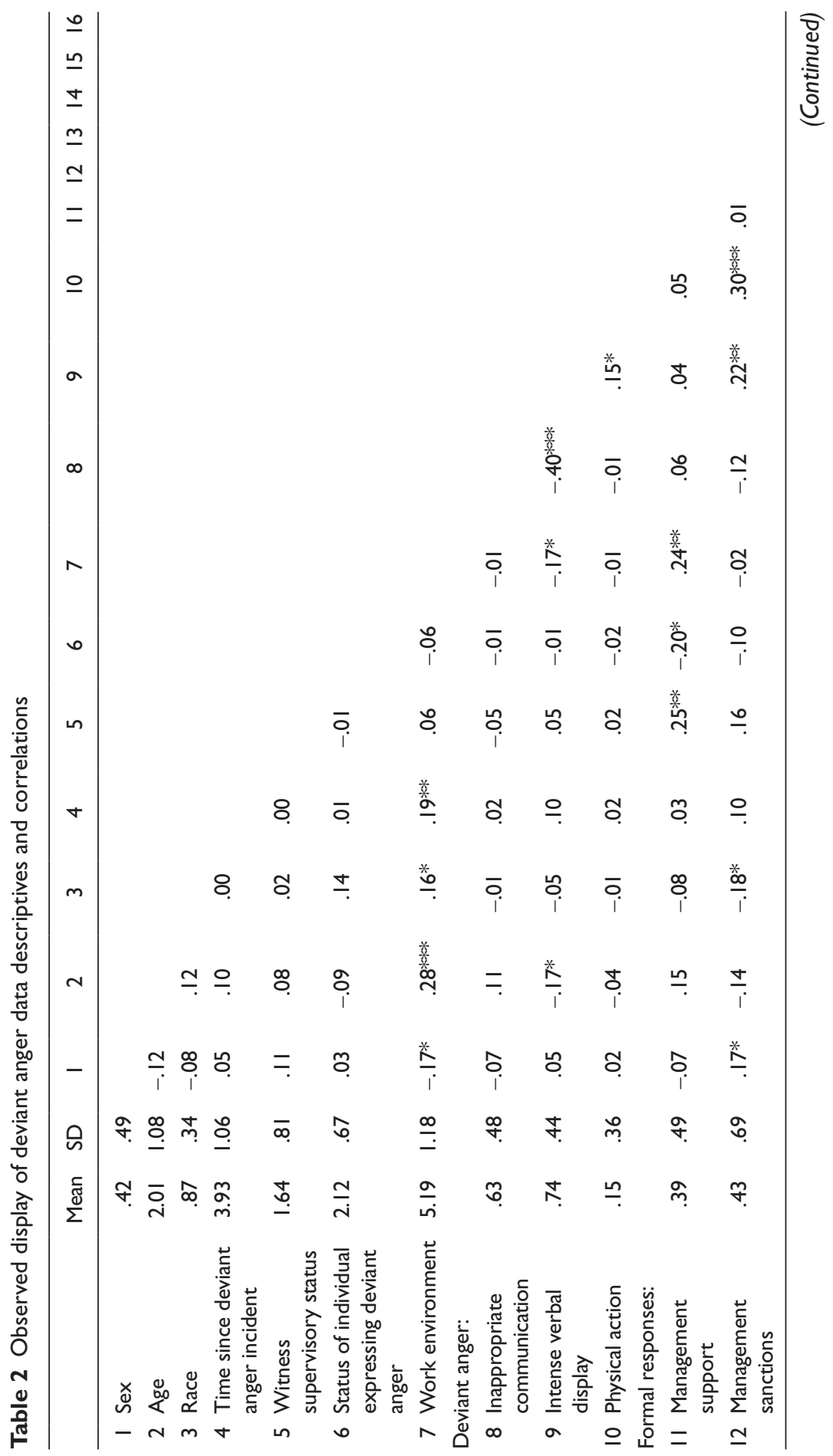




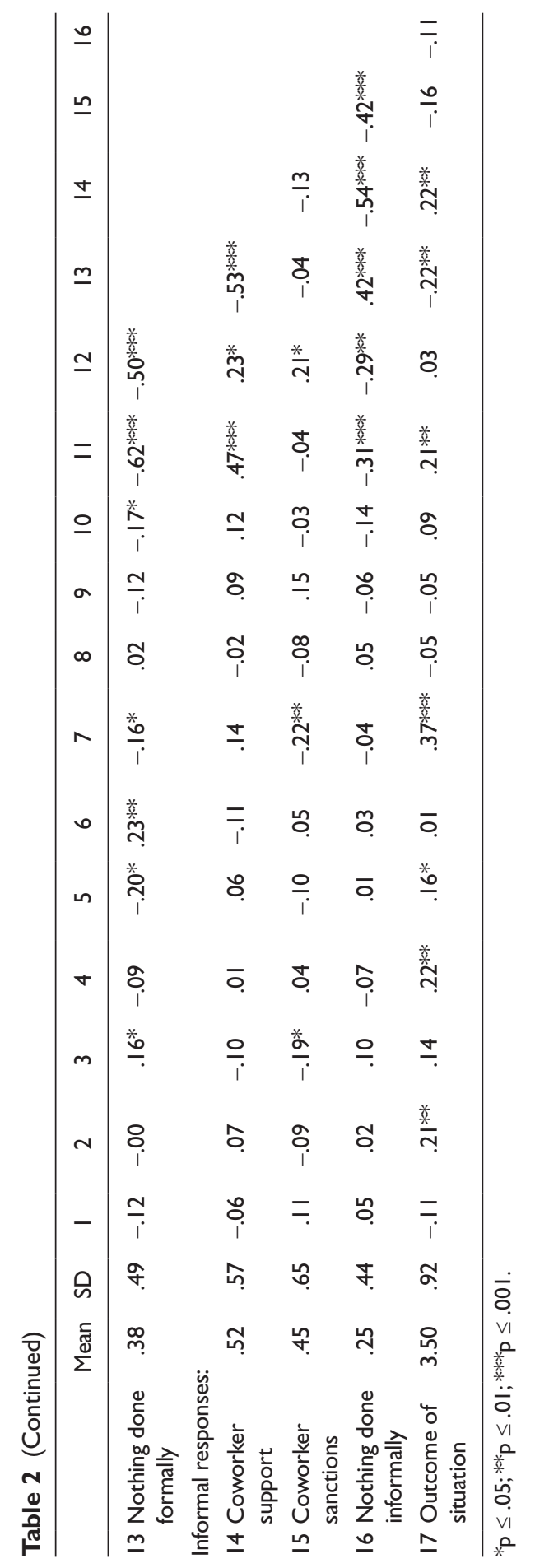




\section{Results}

Several analyses helped determine whether data collected from different sources could be aggregated. First, we compared each anger item for similarity across our four samples by running ANOVAs, followed by a Tukey post hoc on the items with significant ANOVAs. For most ANOVAs, there were no significant differences between samples. However, to further assess this, the data site collection variable was dummy coded and included in our initial analyses. Since no site variable achieved significance in our models, we removed it as a control in subsequent analyses.

Given the categorical nature of our data, we tested our hypotheses using generalized linear models $(\mathrm{GLM})^{3}$ with maximum likelihood estimates. GLM support a number of non-parametric dependent variables including binary, categorical, and count data (Garson, 2008), and maximum likelihood estimates are recommended because they do not require an assumption of normal distributions (Agresti, 2007).

Table 2 reports descriptive statistics and correlations for variables relevant to the observed deviant anger display. Respondents reported observing deviant workplace anger more than six months ago (39\%), within the previous month (33\%), or during the past one to six months $(28 \%)$. They characterized deviant anger displays as intense verbal displays (75\%), inappropriate communication (62\%), and physical actions (15\%). Survey participants also indicated that of the deviant anger displays known to management, 35 percent received no formal response, 37 percent received a supportive management response, and 28 percent prompted management sanctions. Further, respondents indicated that following the deviant anger display, 24 percent of employees experienced no coworker response, while 43 percent received coworker support, and 33 percent experienced coworker sanctions. ${ }^{4}$

Hypotheses $1 \mathrm{a}$ and $1 \mathrm{~b}$ predicted negative consequences for organizational members who express deviant anger in the form of physical acts or intense verbal displays. In this analysis, the dependent variables were formal and informal sanctions, respectively, and the independent variables were the three categories of deviant anger. Table 3 lists results from the generalized linear models testing these hypotheses. The likelihood ratio $X^{2}$ is the overall test of model significance, and the Wald $X^{2}$ statistic indicates the significance of individual predictor variables. GLM calculates a parameter estimate for every possible value of control and predictor variables; thus, we only report betas for significant parameters. The likelihood ratio chi-square test was significant for our management sanctions model $\left(X^{2}=34.20, p<.01\right)$, but not in the coworker sanctions model $\left(X^{2}=18.79, p=.22\right)$. Hypothesis 1a received partial support given a significant coefficient for physical actions $(\mathrm{B}=.53, \mathrm{SE}=.16, p<.001)$, indicating that these deviant anger displays were the most likely to result in formal sanctions by management. Hypothesis $1 \mathrm{~b}$ predicted that informal sanctions also followed deviant anger expressed as physical acts or intense verbal displays. This was not supported given an overall non-significant model.

In both models, race was the only significant control variable predictive of observed sanctioning behaviors. Non-white witnesses were more likely than white witnesses to perceive sanctioning behavior by both management $(\mathrm{B}=-.47, \mathrm{SE}=18, p<.01)$ and coworkers $(\mathrm{B}=-.38, \mathrm{SE}=.17, p<.05)$ following deviant anger expression. Also, in the 
Table 3 Wald chi-square statistics for predictors of sanctions following deviant anger display

\begin{tabular}{|c|c|c|c|c|}
\hline & \multicolumn{2}{|c|}{$\begin{array}{c}\text { Formal response: } \\
\text { Management } \\
\text { sanctions }\end{array}$} & \multicolumn{2}{|c|}{$\begin{array}{l}\text { Informal response: } \\
\text { Coworker sanctions }\end{array}$} \\
\hline & Wald $\chi^{2}$ & d.f. & Wald $\chi^{2}$ & d.f. \\
\hline Intercept & $5.86 *$ & I & 5.53 & I \\
\hline Sex & .39 & I & .85 & I \\
\hline Age & 1.11 & 4 & .91 & 4 \\
\hline Race & $7.05 * *$ & I & $5.16 *$ & I \\
\hline Witness supervisory status & $10.49 *$ & 3 & .94 & 3 \\
\hline Status of individual expressing deviant anger & .26 & 2 & 1.16 & 2 \\
\hline Work environment & .28 & I & 1.30 & I \\
\hline Inappropriate communication & 1.03 & I & .56 & I \\
\hline Intense verbal display & 1.61 & 1 & 2.78 & I \\
\hline Physical action & $10.82^{* * *}$ & i & .46 & i \\
\hline Likelihood ratio chi-square & $34.28 * *$ & 15 & 18.79 & 15 \\
\hline
\end{tabular}

$*_{\mathrm{p}} \leq .05 ; * * \mathrm{p} \leq .01 ; * * * \mathrm{p} \leq .001$.

Note. Chi squares do no reflect the sign of the parameter estimates for predictor variables.

However, race (specifically non-white) was associated with perceptions of sanctioning. All other significant predictors were positively related to perceived sanctions.

management sanctions model, witness supervisory status was significant, indicating that those who supervised more than 25 employees $(\mathrm{B}=.65, \mathrm{SE}=.25, p<.001)$ were more likely to observe formal sanctioning than those who were not in a management position.

Hypotheses $3 \mathrm{a}$ and $3 \mathrm{~b}$ asserted supportive work environments would increase more supportive, less-punitive responses to deviant anger by managers and coworkers, respectively. GLM analysis indicated that supportive work environment $(\mathrm{B}=.10, \mathrm{SE}=.03$, $p<.01$ ) was a significant predictor of a formal supportive response following deviant anger displays. The overall model was also significant $\left(X^{2}=36.05, p<.01\right)$, supporting Hypothesis $3 \mathrm{a}$. For the coworker support model, supportive work environment $(\mathrm{B}=.07$, $\mathrm{SE}=.04, p=.09$ ) was in the predicted direction, but did not reach conventional levels of significance. Further, the overall model was not significant $\left(X^{2}=14.88, p=.46\right)$; thus, Hypothesis 3 b was not supported (see Table 4).

Control variables significant in the management support model included witness supervisory status and subordinate status for the angry employee. Significant differences were observed between non-manager respondents and respondents who supervised between 11 and 25 employees $(\mathrm{B}=.49, \mathrm{SE}=.16, p<.01)$, indicating those in a supervisory position with this range of control were more likely than non-manager respondents to witness formal support toward individuals expressing deviant anger. Also, when the individual expressing deviant anger was subordinate to the individual prompting the anger incident $(\mathrm{B}=.30, \mathrm{SE}=.12, p<.05)$, more supportive responses by management were likely than when the angry employee had higher status.

Table 5 reports GLM results for management and coworker responses relevant to situational change. Hypotheses $2 \mathrm{a}$ and $4 \mathrm{a}$ examined the impact of formal management sanction and support, respectively, on the problematic situation. Control variables were entered 
Table 4 Wald chi-square statistics for predictors of support following deviant anger display

\begin{tabular}{|c|c|c|c|c|}
\hline & \multicolumn{2}{|c|}{$\begin{array}{c}\text { Formal response: } \\
\text { Management support }\end{array}$} & \multicolumn{2}{|c|}{$\begin{array}{l}\text { Informal response: } \\
\text { Coworker support }\end{array}$} \\
\hline & Wald $\chi^{2}$ & d.f. & Wald $\chi^{2}$ & d.f. \\
\hline Intercept & .00 & I & 1.90 & I \\
\hline Sex & .01 & I & 1.17 & I \\
\hline Age & 6.82 & 4 & 2.38 & 4 \\
\hline Race & 1.36 & 1 & 2.51 & I \\
\hline Witness supervisory status & $12.09 * *$ & 3 & 1.40 & 3 \\
\hline Status of individual expressing deviant anger & $6.40 *$ & 2 & 4.22 & 2 \\
\hline Inappropriate communication & .71 & 1 & .00 & I \\
\hline Intense verbal display & 1.69 & I & .80 & I \\
\hline Physical action & .73 & I & 1.24 & I \\
\hline Work environment & $8.08 * *$ & 1 & 2.90 & 1 \\
\hline Likelihood ratio chi-square & $36.05 * *$ & 15 & 14.86 & 15 \\
\hline
\end{tabular}

${ }_{\mathrm{p}} \leq .05 ; * * \mathrm{p} \leq .01 ; * * * \mathrm{p} \leq .001$.

Note: Chi squares do not reflect the sign of the parameter estimates for predictor variables.

However, supervisory status of the angry employee was negatively associated with perceptions of supportive responses. All other significant variables are positive predictors.

along with deviant anger and response variables - management sanctions and management support. The omitted formal response variable was 'Management did nothing'. The overall model was significant $\left(X^{2}=37.70 p<.01\right)$, but formal management sanctions were not significant, meaning there was no difference between management sanctioning and management doing nothing on situational change. However, in contrast to doing nothing, when management talked with the employee - the least punitive, most supportive formal response - perceptions of favorable situation change increased significantly $(\mathrm{B}=.40, \mathrm{SE}=.18, p<.05)$. These findings support Hypothesis $4 \mathrm{a}$, but not $2 \mathrm{a}$ and are reported in the first column of Table 5 .

Hypotheses $2 b$ and $4 b$ examined the impact of informal coworker sanctions and support, respectively, on the problematic situation. As with the previous analyses, control, deviant anger, and response variables - coworker support and coworker sanctions - were entered in the model. The omitted informal response variable was 'coworkers did nothing'. Results from this analysis are found in the second column of Table 5. The overall model was significant $\left(X^{2}=38.95, p<.01\right)$. In contrast to coworkers doing nothing following a deviant anger incident, a supportive response to the angry individual was a significant, positive predictor for the situation improving $(\mathrm{B}=.59, \mathrm{SE}=.17, p=.00)$. Although in the expected direction, the informal sanctioning options were not significant predictors of negative situational change. Thus, Hypothesis $4 \mathrm{~b}$ was supported, while $2 \mathrm{~b}$ was not.

In the formal response model, several controls were significant predictors of perceived situational change. When the anger incident was over six months ago $(B=.69$, $\mathrm{SE}=.29, p<.05)$, the situation was seen as improved. Also improving the situation was peer status between the angry employee and his or her provocateur $(\mathrm{B}=.52, \mathrm{SE}=.23$, $p<.05)$, and if the deviant anger expressed involved physical action $(\mathrm{B}=.52, \mathrm{SE}=.24$, $p<.05)$. In the informal response model, race was the only significant control. White 
Table 5 Wald chi-square statistics for predictors of situation outcome following organizational Responses to deviant anger

\begin{tabular}{lcccr}
\hline & \multicolumn{3}{c}{ Situational change } \\
\cline { 2 - 5 } & Wald $\chi^{2}$ & d.f. & Wald $\chi^{2}$ & d.f. \\
\hline Intercept & $53.15^{* * *}$ & 1 & $50.24^{* * *}$ & 1 \\
Sex & 2.21 & 1 & .14 & 1 \\
Age & 3.71 & 4 & 2.17 & 4 \\
Race & 1.46 & 1 & $5.68^{*}$ & I \\
Time since incident observed & $8.74^{*}$ & 3 & 8.32 & 4 \\
Status of individual expressing deviant anger & 5.25 & 2 & 2.15 & 2 \\
Work environment & .25 & 1 & .02 & 1 \\
Inappropriate communication & 1.94 & 1 & .20 & 1 \\
Intense verbal display & .19 & 1 & .21 & 1 \\
Physical action & $4.66^{*}$ & 1 & .43 & 1 \\
Formal responses: & & & & \\
$\quad$ Management support & $5.12^{*}$ & 1 & & 2 \\
$\quad$ Management sanctions & .03 & 3 & & 2 \\
Informal responses: & & & $12.61^{* *}$ & .54 \\
$\quad$ Coworker support & & & $38.95^{* *}$ & 20 \\
$\quad$ Coworker sanctions & $37.70^{* *}$ & 19 & & \\
Likelihood ratio chi-square & & & & \\
\hline
\end{tabular}

$*_{\mathrm{p}} \leq .05 ; * * \mathrm{p} \leq .0 \mathrm{I} ; * * * \mathrm{p} \leq .00 \mathrm{I}$.

Note: Chi squares do no reflect the sign of the parameter estimates for predictor variables.

However, all significant predictors had a positive effect on the situational outcome.

witnesses were more likely than non-white witnesses to perceive favorable changes to the initially problematic situation $(\mathrm{B}=.54, \mathrm{SE}=.23, p<.05)$.

\section{Discussion}

Our research sought to better understand organizational observer (i.e. management and coworker) sanctioning and supportive reactions following deviant anger displays at work. We also explored how such organizational observer actions subsequent to deviant anger displays impacted effective situational change in the work environment. Overall, our findings support Dual Threshold Model assertions that organizational observer responses are significant determinants of organizational outcomes and that positive consequences from anger expression can come from supportive work environments and supportive organizational observer responses (Geddes and Callister, 2007).

Perhaps our most noteworthy finding indicates that more supportive responses by management and coworkers following deviant anger promoted favorable situational change at work, while sanctioning or doing nothing did not. In relation, supportive work environments were significantly related to supportive responses by management. Organizational cultures and climates are highly influenced by management action toward employees (Schein, 2004). Thus, when management responds to angry employees in a more supportive than sanctioning manner, they are likely to help establish and reinforce norms and work environments that promote more tolerant, concerned responses toward 
emotional organizational members. Using DTM terminology, these responses help 'expand the space' between the expression and impropriety thresholds (Geddes and Callister, 2007). Although we considered the possibility that a greater (versus lesser) response by organizational observers might have an enhanced effect, it appears that a single act of support by a manager or coworker can significantly improve problematic situations at work.

Findings also indicate that physical anger displays, in particular, promoted formal sanctioning by management. This is also consistent with DTM assertions that when anger displays are perceived as aggression by management, they will likely lead to formal sanctioning at work and, thus, unfavorable outcomes for the angry employee. Surprisingly, physical acts of deviant anger had a significantly positive effect on situational changes at work for the formal response model. It is unclear whether this positive impact reflects supportive responses by management, increased visibility of (and thus, reactions to) the initially problematic situation, the angry employee's termination, or some other explanation. Subsequent analysis indicates that while physical anger displays and dismissal were highly correlated $(r=.25, p=.002)$, there was no association between dismissals and positive situational change $(r=-.02)$. Thus, it is unlikely the perceived improvement came from eliminating a problematic employee. Physical actions did not predict supportive responses by either management or coworker in our previous models (see Table 4). However, our management support variable was a strong predictor of the situation getting better. Thus, perhaps the most likely contributing factor for this surprising relationship is the highly visible nature of physical action, which likely prompts an immediate response by management, and an opportunity to discuss the situation, including attempts to better understand and address the cause of the emotional episode.

Overall, the data challenge traditional views of anger as aggressive acts that damage the organization and/or require formal sanctioning to improve the situation. Instead, data support an emergent approach to anger as reflected in the DTM, which suggests that even intense emotional outbursts can prove informative, and if responded to more compassionately, can lead to favorable change in the organizational. Further, data show that compared with talking with the angry employee, not responding is an ineffective and problematic reaction by organizational observers. Failing to respond does not emerge as a supportive response, nor does it function as one. Instead, it resembles sanctions in its negative, but nevertheless, insignificant impact on favorable situational change at work. Thus, whether operating from a more traditional or emergent view of workplace anger, ignoring deviant anger displays is an ineffective response to emotional episodes at work.

Beyond these key variables, study controls also proved useful, identifying demographic and time factors that influence perceptions surrounding deviant workplace anger. For instance, non-white survey respondents reported witnessing more formal and informal sanctions against employees expressing deviant anger than did white respondents. There are likely varied, plausible explanations for this finding. Given the history of discrimination against ethnic minorities, however, one possibility is that these individuals may be particularly sensitive to, and aware of, organizational sanctions administered to fellow coworkers, especially if they are concerned such acts may reflect prejudicial tendencies. White survey respondents also witnessed less punitive, more formal supportive interactions than did non-white respondents and felt the situation overall did improve. 
However, this may reflect the fact that more whites than non-whites were in a supervisory position ( $86 \%$ versus $14 \%$ ). In addition, organizational status influenced participant perceptions. Managers witnessed more formal supportive and sanctioning behavior than non-manager witnesses. This is not surprising as higher status employees are more likely aware of how management (including themselves) addressed deviant anger incidents. At the same time, managers also could be somewhat biased in their perceptions of formal responses to deviant anger. That is, they may be more motivated to believe that management addressed the situation, and did so effectively, than organizational observers who are not managers.

In addition to the significance of the observer status, the status of the angry employee also proved noteworthy. Our results indicate that employees angered because of their bosses generated more supportive responses from management than if their deviant anger was caused by peers or subordinates. Managers who recognize their role in making an employee angry may be motivated to respond more compassionately to help restore a favorable working relationship. Employees often feel anger in response to perceived injustice by the organizational hierarchy (Bies, 1987); thus, if management demonstrates an active interest in addressing underlying issues that prompted employee anger, perceptions of improved situations could increase significantly. Further, as peer-based angry altercations were the most likely to lead to more positive situational change, this may reflect a higher tendency and/or comfort-level talking things through with a colleague than if the organizational member is angered by a subordinate or boss.

Finally, the significance of the time-since-incident control variable suggests that as time passes, circumstances surrounding deviant anger incidents eventually improve. Anger expression at work may involve complex emotion episodes that require time to process and resolve by management, coworkers, and the angry employee. While the adage 'time heals' is consistent with our findings, we anticipate this healing process should accelerate with more compassionate, less punitive responses by organizational members.

\section{Limitations}

There are limitations to this study that merit mention. Although participating organizations and individuals varied considerably, we acknowledge the non-randomized convenience and social-network sampling associated with study data collection, and recognize that this may limit the generalizability of our findings. Also acknowledged are traditional concerns regarding cross-sectional and self-report data. Nevertheless, owing to the sensitive nature of the phenomenon of interest, confidential and anonymous surveying was an appropriate methodology. Further, given the possibility of social desirability bias, observed deviant anger was deemed preferable over asking individuals to report incidents when they personally expressed anger inappropriately. Nevertheless, there is an inherent weakness to this technique as observers may not be aware of all elements of the anger incident, including causes, sanctions imposed, or specific actions taken to address the underlying problematic situation. Consequently, we included the optional acknowledgment that they didn't know what transpired after the incident. This eliminated several cases from further analysis but increased our confidence in the reports used. The fact that 
approximately half the respondents were managers further suggests these individuals were likely in a position to know how management responded.

Another limitation of self-report questionnaires is the possibility of common method variance (CMV) being artificially inflated as a result of the data collection method (Crampton and Wagner, 1994). Although there is some debate as to the existence of and magnitude that CMV biases results, the general assumption is that it can be a problem in mono-method research (Doty and Glick, 1998; Spector, 1987). Harmon's onefactor test is a diagnostic statistic designed to assess the extent CMV may be a problem in research (Podsakoff and Organ, 1986). The test involves factor analyzing all variables of interest in a study assuming that if a significant amount of CMV is present, a onefactor solution will emerge. We performed this test and results produced six factors with eigenvalues greater than one. Variance explained by those six factors totaled 65.4 percent and ranged from 17.7 percent (factor 1) to 6.3 percent (factor 6). These results indicate that $\mathrm{CMV}$ is not a serious threat in this study.

Finally, use of a single-item dependent variable for situation change is typically not ideal. However, we felt observer perceptions regarding whether the situation remained unchanged, got better, or became worse was a reasonable and accessible data point for a diverse array of anger episodes as well as a valid organizational member perception. For instance, in medical research, Gestalt patient impressions of health, (i.e. how are you feeling today?) are found to be valid indicators of improving or deteriorating personal health (Bowling, 2005). We felt a similar observer perception could prove valid as an indicator of relevant workplace well-being. Given this, we also recognize that perceived change is a highly complex variable. It entails perceptions of personal (actor and observer) and organizational benefits/harm, as well as specific details regarding what changed that made a difference. This is a rich area for future study to better decipher how situations 'improve' or 'deteriorate' following emotional episodes.

\section{Implications for future research and practice}

Although our research provides empirical support for the Dual Threshold Model, more research is required to examine its numerous components and propositions. For instance, beyond the scope of this preliminary research are individual trait and personality differences noted as factors determining threshold crossing behavior (Geddes and Callister, 2007). Further, Geddes and Callister identify key message characteristics and argue that expressions of anger reflecting alter-centric (versus egocentric) concerns, exhibiting limited intensity markers, and those that are relatively infrequent will be more likely to promote favorable responses by organizational members. Thus, we anticipate message characteristics, perceived intent, and display frequency will be critical in determining anger's acceptability by organizational observers.

Although the DTM specifically identifies actors versus observers in their organizational member differentiation, whether or not the observer of anger is a target or merely a witness might have a significant impact on how he or she views the overall situation as well as how likely, as a coworker or management, this person will respond supportively (see Gibson and Callister, 2010). In other words, it might be easier for a witness of an employee expressing anger, or others such as management who learn of the incident 
secondhand, to show concern and support if they are not the target of the anger display. Thus, future research should consider the moderating effect of the position played by the organizational observer (witness, target, or consultant) in an emotional episode.

Zero-tolerance policies and behavior-outcome contingencies are a relatively recent product of research addressing workplace aggression and deviance with its focus on anger's potentially damaging effects. Nevertheless, Lucero and Allen (2006) indicate, as a result of their 30 years studying violent and dysfunctional workplace behaviors, that 'overly zealous administration of policies including those supporting zero tolerance can make the problem worse if enforcement is viewed as unfair by employees' (p. 36). They argue that a fundamental determination, in order to provide an appropriate response, is consideration of just cause, which helps adjudicators better examine expressed anger in relation to its provocation. Such considerations may ensure management sanctions are not perceived as arbitrary, extreme, or a violation of a psychological contract, increasing perceptions of procedural fairness by both observers and those expressing anger (Cropanzano et al., 2000; Morrison and Robinson, 1997). Thus, future research should examine expressions of anger and subsequent formal and informal responses as they relate to organizational justice, to better determine how involved parties apply just cause standards and identify mitigating circumstances.

Practical applications of our research suggest that more favorable changes and organizational outcomes may follow workplace anger expressions if training and socialization efforts include explanations of potential benefits from active, tolerant, and concerned responses, thus reducing indifference, ostracism, or retaliation. Business codes of conduct are often about what we shouldn't do as actors in emotional episodes, while few, if any, tend to address our role as observers of emotional episodes. Such guidelines, if available, could expand to include suggestions for those who witness, judge, and respond to angry employees - formally or informally. For instance, one recommendation could be for witnesses of employee anger to consider that the individual may have just cause for their outrage, and to not retaliate aggressively, but instead try to respond with interest and concern. If the display is physical, the witness could be instructed to immediately notify their manager to personally handle the situation.

Management training also may help individuals reconsider their traditional perceptions of employee anger. Rather than view these expressions as inherently hostile acts and/or personal affronts or challenges to authority, management could be taught to recognize that employee anger helps them identify workplace conditions requiring significant and/or immediate attention. Anger expressions may be better viewed - conceptually and practically - as focused forms of employee dissent or voice (Geddes and Callister, 2007; Van Dyne et al., 1995; Van Dyne et al., 2003), by which the employee confronts inefficient, unjust, and/or offensive workplace situations. With this perceptual shift, management may benefit from responding to intense anger expressions in a more problem-solving, emotionally-tolerant manner, to help foster ongoing communication and trust (Elsbach and Elofson, 2000).

In summary, all anger expressed at work will not necessarily benefit the organization or its members. Anger displays that truly reflect an aggressive, harmful intent, in particular, are socially unacceptable and should be appropriately sanctioned. Hostile and violent employees in the work environment should be removed. Nevertheless, we argue that 
much of the anger expressed at work is not a marker of hostility but instead reflects provocative circumstances that violate salient social norms of organizational members. Further, our findings support DTM assertions that how organizational observers respond to anger expressed at work, more than the emotional display itself, determines whether beneficial or detrimental outcomes result for organizations and its members. Future research examining anger's impact at work should continue to recognize and examine the dynamic, complex, and interactive arena in which these emotional episodes are enacted.

\section{Notes}

1. Two answers could not be categorized and were omitted in this analysis. These were in response to the question about informal organization responses: 'We felt the same way but handled the situation differently', and 'try to make the best of the situation, since we're all at work'.

2. Most survey respondents indicated either a supportive or sanctioning response to the deviant anger display. In a minority of cases (13\%), they reported knowledge of both sanctioning and supportive responses.

3. Sometimes abbreviated as GZLM, the Generalized Linear Model (GLM) is an extension of the General Linear Model but a separate analysis with different assumptions. GLM is appropriate for use with variables that follow any probability distribution in the exponential family of distributions. In particular, GLM is appropriate when response variables do not have normal distribution, such as categorical and nominal data, and when there is no assumption of homogeneity of variance.

4. Although we use combined support and sanction response options for our analyses, the following indicate frequency of each response option. In situations prompting a formal sanction, management issued a written warning $(20 \%)$, initiated probation $(5 \%)$, suspension $(2 \%)$, and/or dismissed the angry employee (12\%). Anger displays prompting an informal supportive response included coworkers talking non-assertively (34\%) and assertively $(15 \%)$ while those prompting coworker sanctions experienced coworker distancing $(33 \%)$ and verbal aggressiveness (11\%).

\section{Acknowledgements}

The authors gratefully acknowledge Associate Editor, Professor Gail Fairhurst, and the three anonymous reviewers for their helpful guidance and commentary regarding this manuscript.

\section{Funding}

This research received no specific grant from any funding agency in the public, commercial, or not-for-profit sectors.

\section{References}

Agresti A (2007) An Introduction to Categorical Data Analysis, 2nd edn. Hoboken, NJ: WileyInterscience.

Andersson LM and Pearson CM (1999) Tit for tat? The spiraling effect of incivility in the workplace. Academy of Management Review 24(3): 452-471.

Aquino K, Douglas S and Martinko MJ (2004) Overt anger in response to victimization: Attributional style and organizational norms as moderators. Journal of Occupational Health Psychology 9(2): 152-164. 
Ashforth BE and Humphrey RH (1995) Emotion in the workplace: A reappraisal. Human Relations 48(2): 97-126.

Ashkanasy NM, Zerbe WJ and Härtel CEJ (2002) Managing Emotions in the Workplace. Armonk, NY: M.E. Sharpe.

Averill JR (1979) Anger. In: Dienstbier RA (ed) Nebraska Symposium on Motivation (Vol. 26). Lincoln, NE: University of Nebraska Press, 1-80.

Averill JR (1982) Anger and Aggression: An Essay on Emotion. New York, NY: Springer-Verlag.

Averill JR (1993) Illusions of anger. In: Felson RB and Tedeschi JT (eds) Aggression and Violence: Social Interactionist Perspectives. Washington, DC: American Psychological Association, 171-193.

Baron RA and Neuman JH (1998) Workplace aggression - the iceberg beneath the tip of workplace violence: Evidence on its forms, frequency, and targets. Public Administration Quarterly 21(4): 446-464.

Baron RA, Neuman JH and Geddes, D (1999) Social and personal determinants of workplace aggression: Evidence for the impact of perceived injustice and the Type A behavior pattern. Aggressive Behavior 25(4): 281-296.

Bies RJ (1987) The predicament of injustice: The management of moral outrage. In: Cummings LL and Staw BM (eds) Research in Organizational Behavior (Vol. 9). Greenwich, CT: JAI Press Inc, 289-319.

Bies RJ, Tripp TM and Kramer RM (1997) At the breaking point: Cognitive and social dynamics of revenge in organizations. In: Giacalone RA and Greenberg J (eds) Antisocial Behavior in Organizations. Thousand Oaks, CA: SAGE, 18-36.

Bowling A (2005) Just one question: If one question works, why ask several? Journal of Epidemiology and Community Health 59(5): 342-345.

Burleson BR (1994) Comforting messages: Features, functions, and outcomes. In: Synpher HE and Applegate JL (eds) Strategic Interpersonal Communication. Hillsdale, NJ: Erlbaum, 135-161.

Burleson BR (2003) The experience and effects of emotional support: What the study of cultural and gender differences can tell us about close relationships, emotion and interpersonal communication. Personal Relationships 10(1): 1-23.

Canary DJ, Spitzberg BH and Semic BA (1998) The experience and expression of anger in interpersonal settings. In: Andersen PA and Guerrero LK (eds) Handbook of Communication and Emotion: Research, Theory, Application, and Contexts. New York: Academic Press Inc, 189-213.

Clore GL and Ortony A (1991) What more is there to emotion concepts than prototypes? Journal of Personality \& Social Psychology 60(1): 48-50.

Clore GL, Gasper K and Garvin E (2001) Affect as information. In: Forgas JP (Ed) Handbook of Affect and Social Cognition. Mahwah, NJ: Lawrence Erlbaum Associates, 121-144.

Cohen S and Wills TA (1985) Stress, social support, and the buffering hypothesis. Psychological Bulletin 98(28): 310-357.

Côté S (2005) A social interaction model of the effects of emotion regulation on work strain. Academy of Management Review 30(3): 509-530.

Crampton SM and Wagner JA (1994) Percept-percept inflation in microorganizational research: An investigation of prevalence and effect. Journal of Applied Psychology 79(1): 67-76.

Cropanzano R, Weiss HM, Suckow KJ and Grandey AA (2000) Doing justice to workplace emotion. In: Ashkanasy NM, Härtel CEJ and Zerbe WJ (eds) Emotions in the Workplace: Research, Theory, and Practice. Westport, CT: Quorum Books, 49-62. 
Doty DH and Glick WH (1998) Common methods bias: Does common methods variance really bias results? Organizational Research Methods 1(4): 374-406.

Dutton JE, Worline MC, Frost PJ and Lilius J (2006) Explaining compassion organizing. Administrative Science Quarterly 51(1): 59-96.

Ellis DG (2001) Language and civility: The semantics of anger. In: Eadie WF and Nelson PE (eds) The Language of Conflict and Resolution. Thousand Oaks, CA: SAGE, 105-120.

Elsbach KD and Elofson G (2000) How the packaging of decision explanations affects perceptions of trustworthiness. Academy of Management Journal 43(1): 80-89.

Fineman S (1993) Emotion in Organizations. Newbury Park, CA: SAGE.

Fineman S (2000) Emotion in Organizations, 2nd edn. Thousand Oaks, CA: SAGE.

Fox S and Spector PE (1999) A model of work frustration-aggression. Journal of Organizational Behavior 20(6): 915-931.

Friedman R, Anderson C, Brett J, Olekalns M, Goates N and Lisco CC (2004) The positive and negative effects of anger on dispute resolution: Evidence from electronically mediated disputes. Journal of Applied Psychology 89(2): 369-376.

Garson GD (2008) Generalized Linear Models and Generalized Estimating Equations. Available at: http://faculty.chass.ncsu.edu/garson/pa765/statnote.htm

Geddes D and Baron RA (1997) Workplace aggression as a consequence of negative performance feedback. Management Communication Quarterly 10(4): 433-454.

Geddes D and Callister RR (2007) Crossing the line(s): A dual threshold model of anger in organizations. Academy of Management Review 32(3): 721-746.

Giacalone RA and Greenberg J (eds) (1997) Antisocial Behavior in Organizations. Thousand Oaks, CA: SAGE.

Gibson DE and Callister RR (2010) Anger in organizations: Review and integration. Journal of Management 36(1): 66-93.

Gibson DE, Schweitzer ME, Callister RR and Gray B (2009) The influence of anger expressions on outcomes in organizations. Negotiation and Conflict Management Research 2(3): 236-262.

Goleman D (1995) Emotional Intelligence. New York, NY: Bantam Books.

Gross JJ and John OP (2003) Individual differences in two emotion regulation processes: Implications for affect, relationships, and well-being. Journal of Personality and Social Psychology 85(2): 348-362.

Guetzkow H (1950) Unitizing and categorizing problems in coding qualitative data. Journal of Clinical Psychology 6(1): 47-58.

Hatfield E, Cacioppo JT and Rapson RL (1994) Emotional Contagion. Paris: Cambridge University Press.

Huy QN (1999) Emotional capability, emotional intelligence, and radical change. Academy of Management Review 24(2): 325-345.

Jones EE and Nisbett RE (1972) The actor and the observer: Divergent perceptions of the causes of behavior. In: Jones EE, Kanouse DE, Kelley HH, Nisbett RE, Valins S and Weiner B (eds) Attribution: Perceiving the Causes of Behavior. Morristown, NJ: General Learning Press, 79-94.

Kanov JM, Maitlis S, Worline MC, Dutton JE, Frost PJ and Liltus JM (2004) Compassion in organizational life. American Behavioral Scientist 47(6): 808-827.

Kiefer T (2002) Understanding the emotional experience of organizational change: Evidence from a merger. Advances in Developing Human Resources 4(1): 39-61. 
Kramer MW and Hess JA (2002) Communication rules for the display of emotions in organizational settings. Management Communication Quarterly 16(1): 66-80.

Lee K and Allen NJ (2002) Organizational citizenship behavior and workplace deviance: The role of affect and cognitions. Journal of Applied Psychology 87(1): 131-142.

Lord RG, Klimoski RJ and Kanfer R (2002) Emotions in the Workplace: Understanding the Structure and Role of Emotions in Organizational Behavior. San Francisco: Jossey-Bass.

Lovaglia MJ and Houser JA(1996) Emotional reactions and status in groups. American Sociological Review 61(5): 867-883.

Lucero MA and Allen RE (1998) Fighting on the job. Dispute Resolution Journal 53(3): 50-57.

Lucero MA and Allen RE (2006) Implementing zero tolerance policies: Balancing strict enforcement with fair treatment. SAM Advanced Management Journal (1984) 71(1): 35-41.

Malle BF, Knobe J and and Nelson S (2007) Actor-observer asymmetries in explanations of behavior: New answers to an old question. Journal of Personality and Social Psychology 93(4): 491-514.

Mastenbroek W (2000) Organizational behavior as emotion management. In: Ashkanasy NM, Hartel CE and Zerbe WJ (eds) Emotions in the Workplace: Research, Theory and Practice. Westport, CT: Quorum Books, 19-35.

Meyerson DE (2000) If emotions were honoured: A cultural analysis. In: Fineman S (ed) Emotion in Organizations, 2nd ed. Thousand Oaks, CA: SAGE, 167-183.

Mikulincer M (1998) Adult attachment style and individual differences in functional versus dysfunctional experiences of anger. Journal of Personality and Social Psychology 74(2): 513-524.

Milliken FJ, Morrison EW and Hewlin PF (2003) An exploratory study of employee silence: Issues that employees don't communicate upward and why. Journal of Management Studies 40(6): 1453-1476.

Morrill C (1989) The management of managers: Disputing in an executive hierarchy. Sociological Forum 4(3): 387-408.

Morrison EW and Milliken FJ (2000) Organizational silence: A barrier to change and development in a pluralistic world. Academy of Management Review 25(4): 706-725.

Morrison EW and Robinson SL (1997) When employees feel betrayed: A model of how psychological contract violation develops. Academy of Management Review 22(1): 226-256.

Nelson G and Dyck J (2005) Forbearance in leadership: Opportunities and risks involved in cutting followers some slack. Leadership Quarterly 16(1): 53-70.

Neuman JH and Baron RA (1998) Workplace violence and workplace aggression: Evidence concerning specific forms, potential causes, and preferred targets. Journal of Management 24(3): $391-419$.

Nonaka I, Toyama R and Byosiere P (2001) A theory of organizational knowledge creation: Understanding the dynamic process of creating knowledge. In: Dierkes M (ed) Handbook of Organizational Learning and Knowledge. New York: Oxford University Press, 492-517.

Perlow L and Williams S (2003) Is silence killing your company? Harvard Business Review 81(5): 52-58.

Pinder CC and Harlos KP (2001) Employee silence: Quiescence and acquiescence as responses to perceived injustice. In: Ferris GR (ed) Research in Personnel and Human Resources Management (Vol. 20). US: Elsevier Science/JAI Press, 331-369.

Podsakoff PM and Organ DW (1986) Self-reports in organizational research: Problems and prospects. Journal of Management 12(4): 531-544. 
O'Leary-Kelly AM, Griffin RW and Glew DJ (1996) Organization-motivated aggression: A research framework. Academy of Management Review 21(1): 225-253.

Rafaeli A and Sutton RI (1989) The expression of emotion in organizational life. In: Cummings LL and Staw BM (eds) Research in Organizational Behavior (Vol. 11). Greenwich, CT: JAI Press, 1-42.

Reich WT (1989) Speaking of suffering: A moral account of compassion. Soundings 72(1): 83-108.

Robinson SL and Bennett RJ (1995) A typology of deviant workplace behaviors: A multidimensional scaling study. Academy of Management Journal 38(2): 555-572.

Robinson SL and O'Leary-Kelly AM (1998) Monkey see, monkey do: The influence of work groups on the antisocial behavior of employees. Academy of Management Journal 41(6): 658-672.

Ross LD (1977) The intuitive psychologist and his shortcomings: Distortions in the attribution process. Advances in Experimental Social Psychology (Vol. 10). New York: Random House, $173-220$.

Schein EH (2004) Organizational Culture and Leadership, 3rd edn. San Francisco, CA: Jossey-Bass.

Sereno KK, Welch M and Braaten D (1987) Interpersonal conflict: Effects of variations in manner of expressing anger and justification for anger upon perceptions of appropriateness, competence, and satisfaction. Journal of Applied Communication Research 15(1/2): 128-143.

Skarlicki DP and Folger R (1997) Retaliation in the workplace: The roles of distributive, procedural, and interactional justice. Journal of Applied Psychology 82(3): 434-443.

Sloan MM (2004) The effects of occupational characteristics on the experience and expression of anger in the workplace. Work \& Occupations 31(1): 38-82.

Spector PE (1987) Method variance as an artifact in self-reported affect and perceptions at work: Myth or significant problem? Journal of Applied Psychology 72(3): 438-443.

Spielberger CD, Johnson EH, Russell SF, Crane RJ, Jacobs GA and Worden TJ (1985) The experience and expression of anger: Construction and validation of an anger expression scale. In: Cheney MA and Rosenman RH (eds) Anger and Hostility in Cardiovascular and Behavioral Disorders. New York, NY: McGraw-Hill, 5-30.

Spreitzer GM and Sonenshein S (2003) Positive deviance and extraordinary organizing. In: Cameron K, Dutton J and Quinn R (eds) Positive Organizational Scholarship. San Francisco, CA: Berrett-Koehler, 207-224.

Spreitzer GM and Sonenshein S (2004) Toward the construct definition of positive deviance. American Behavioral Scientist 47(6): 828-847.

Tavris C (1982) Anger, the Misunderstood Emotion. New York: Simon and Schuster.

Tavris C (1984) On the wisdom of counting to ten: Personal and social dangers of anger expression. In: Shaver P (ed) Review of Personality \& Social Psychology (Vol. 5). Newbury Park, CA: SAGE, 170-192.

Tepper BJ (2000) Consequences of abusive supervision. Academy of Management Journal 43(2): $178-190$.

Tiedens LZ (2000) Powerful emotions: The vicious cycle of social status positions and emotions. In: Ashkanasy NM, Hartel CEJ and Zerbe WJ (eds) Emotions in the Workplace: Research, Theory, and Practice. Westport, CN: Quorum Books, 71-81.

Torestad B (1990) What is anger provoking? A psychophysical study of perceived causes of anger. Aggressive Behavior 16(1): 9-26.

Van Dyne L, Ang S and Botero IC (2003) Conceptualizing employee silence and employee voice as multidimensional constructs. Journal of Management Studies 40(6): 1359-1391. 
Van Dyne L, Cummings LL and McLean Parks J (1995) Extra-role behaviors: In pursuit of construct and definitional clarity (a bridge over muddied waters). In: Cummings LL and Staw BM (eds) Research in Organizational Behavior (Vol. 17). Greenwich, CT: JAI Press, 215-285.

Van Emmerik IJH, Euwema MC and Bakker AB (2007) Threats of workplace violence and the buffering effect of social support. Group and Organization Management 32(2): 152-175.

Viswesvaran C, Sanchez JI and Fisher J (1999) The role of social support in the process of work stress: A meta-analysis. Journal of Vocational Behavior 54(2): 314-334.

Warren DE (2003) Constructive and destructive deviance in organizations. Academy of Management Review 28(4): 622-632.

Weiss HM and Cropanzano R (1996) Affective events theory: A theoretical discussion of the structure, causes and consequences of affective experiences at work. In: Cummings LL and Staw BM (eds) Research in Organizational Behavior (Vol. 18). Greenwich, CT: JAI Press, 1-74.

Youndt MA, Snell SA, Dean JW, Jr and Lepak DP (1996) Human resource management, manufacturing strategy, and firm performance. Academy of Management Journal 39(4): 836-866.

Deanna Geddes is Associate Professor and Chair of the Human Resource Management Department at Temple University's Fox School of Business and Management. She also currently serves as Chair the Conflict Management Division of the Academy of Management. Her research interests include workplace anger and aggression, organizational emotions, and issues associated with providing effective performance feedback. Her conceptual and empirical work is published in Academy of Management Review, Academy of Management Learning \& Education, Human Relations, International Journal of Conflict Management, Management Communication Quarterly, Aggressive Behavior, and others. [Email: geddes@temple.edu]

Lisa T Stickney is an Assistant Professor of Management at the University of Baltimore. Her research interests include anger in organizations, emotional contagion, gender studies, and contingent workers. Her research is published in Sex Roles: A Journal of Research. [Email: Lstickney@, ubalt.edu] 